\title{
User Centered Design Approach to Redesign Graduate Student Management Information System
}

\author{
Fanindia Purnamasari $^{1^{*}}$, Noraidah Sahari Ashaari ${ }^{2}$ \\ ${ }^{1,2}$ Universiti Kebangsaan Malaysia
}

\begin{abstract}
This study conducted a user centered design approach based on user perception using the Graduate Student Information System. This study start by requirement gathering employs interview method with discussing about its interface design and its available menu. Then following as design, evaluation and delivery to actual user. The proposed design is evaluated by 30 respondent using questionnaire The findings from the analyzed result show that usability factor encountered by user that has high average mean was interface standard. The study prove that the current system needs to improve from functionality aspect. The proposed system is expected to help the administration task.
\end{abstract}

Keyword: Student Information system, functionality, usability, user centered design.

\begin{abstract}
Abstrak. Penelitian ini melakukan pendekatan desain berpusatkan pemakai berdasarkan persepsi pemakai saat menggunakan Sistem Informasi Mahasiswa Pascasarjana. Penelitian ini dimulai dengan pengumpulan kebutuhan melalui metode wawancara untuk mendiskusikan desain antarmuka dan menu yang tersedia. Seterusnya diikuti tahap desain, evaluasi dan pengiriman kepada pemakai sebenarnya. Desain yang diusulkan dievaluasi oleh 30 responden menggunakan kuesioner. Temuan dari hasil analisis menunjukan bahwa faktor kegunaan yang dihadapi pemakai memiliki nilai tinggi pada standar antarmuka. Penelitian ini membuktikan bahwa sistem saat ini perlu ditingkatkan fungsionalitasnya. Sistem yang diusulkan juga diharapkan dapat membantu tugas administrasi.
\end{abstract}

Kata Kunci: Sistem informasi siswa, fungsionalitas, kegunaan, desain antarmuka berpusat pemakai.

Received 05 May 2018| Revised 14 June 2018| Accepted 18 July 2018

\section{Introduction}

Nowadays, the rapid development of technology has impact to facilitate administration in university. This condition support to administration staff to develop student information system based on standalone, client server, web based system and cloud system. Various of function and facility is provided to student enrollment, academic record database, course registration, and many more that related to academic. Recently, necessary of information system has increased in accordance with specific requirement. Altough development of web based student information

\footnotetext{
*Corresponding author at: Universiti Kebangsaan Malaysia, 43600 Bangi, Selangor, Malaysia

E-mail address: fanindia.purnama@gmail.com
} 
system is important. There is several factor should be consider to meet the non functional requirement besides the requirement [1]. First, able to practice means the basic of requirements for information system as well as to consider develop because its functionality is important. Second, security means the system should be consider privacy setting. The privacy setting can be created with differentiate level of users such as administrator, lecturer and student which support their operation based on their responsibility and authority. Third, make the system in stable condition which ensuring the efficient and effective operation. The developer should ensuring the response time to load system to avoid heavy traffic, able to access in everywhere and control user logging to system in short period time. Fourth, it is compatibility. Information system should include functions needed by different department with different function and applications such as financial system, graduation system and e-learning system. In addtion the system should be implement in various operating system and browser. Fifth, it is maintanibility. Maintenance is important factor to lifecycle of the system. The system maintenance should be execute periodically to make system fast and avoid misoperation cause system has crashed. In doing maintanance is expected to make interface easy to use without change previous version operation to new one.

The process of system design demands skills and knowledge in various domain and purposes. In communication perspective, a system is digital media to deliver information to user. Web developers are need to combine word, graphics, and other multimedia element for develop effective communication between users. From functionality perspective, a system should provide a whole function which fulfil the user requirement. The development of web based student information system is supported by several factors such as able to provide 24 hours transaction service, access to student report, and integrate one system to another system [2]. In addition, system need provide online services such as student form download and two way communication [3]. From Human Computer Interaction (HCI) perspective, a system has to be design in a user friendly and acceptable format to user which involves a system usability, a system accesibility and navigation. Several studies can be found related to different aspect of HCI such analysis of human factor, identify design criteria of system, formulate the evaluation based on HCI standards [4]. Yet, choice of usability element to evaluate should be considered since inaccuracy element choice make resistance to evaluate web usability [5].

Therefore, in this study we will propose UCD method to develop system which meet user requirement To evaluate the system or application, user centered design (UCD) approach is good technique to implement in resarch method. The reason is UCD directly meet user requirement and user evaluation for the system [4], [6]. The previous study that involved user in development process is success to deliver system. Hasan [6] used user testing to evaluate university websites in usability problems, There are three supplementary technique which is used such as observations, quantitative data from post-test questionnaire and qualitative data from post 
questionnaire. After complete the task given, respondent answer the questionnaire.Usuallly the result of qualitative data based on user actual perform test more detail and accurate than from actual user .

\section{Methodology}

The method used in this study is based on the User Centered Design (UCD) model proposed by [4]. UCD model is a system development model that involves users and applies iteratively. The research approach consists of five activities, namely the scope, analysis, design, validation and delivery. Figure 1 shows the UCD study method, the details of this method are stated further.

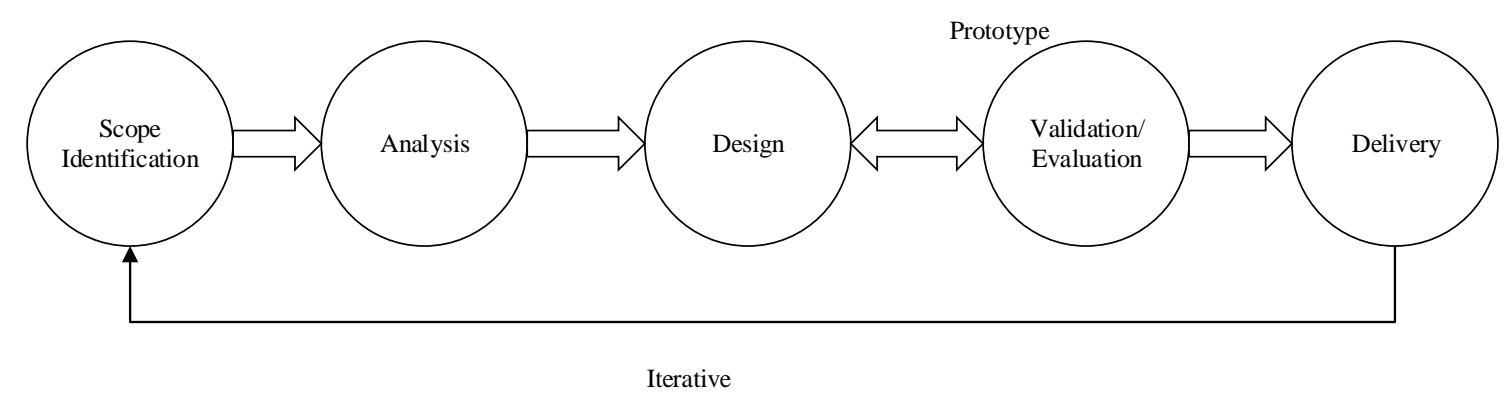

Figure 1. Research Methodology [4]

\subsection{Scope Identification}

In this phase, the researcher defines the scope of the study and obtains research problems involving literature studies to identify current issues in existing student information systems. Furthermore, through literature research the researchers identify the functionality elements that can influence the usefulness of a student information system.

\subsection{Requirement Analysis}

The basic requirement for the design of the student information system is identify the purposes to understand what business process will perform. This analysis require from users perspective is divided into three levels namely administrator, lecturer and student. The selected method in this phase is interview.

\subsubsection{Functional Requirement}

a. Every student should have their accurate identity

b. User can update their personal information and can view the notification about their academic progress

c. Student and lecturer is connected with communication tool

d. The student can apply academic application using system 


\subsubsection{Non-Functional Requirements}

a. Performance Requirement

The proposed system that we are going to redesigning will be used as important medium in campus for helping administrator to manage database of student academic transaction. Therefore, it is expected to provide the function would perform function for all requirement is well. This requirement need to consider because impact to efficiency and effectiveness for user task.

b. Compatibility Requirement

The proposed system should be integrate to another system and able to adapt new environment in order to get system updated.

c. Maintenance Requirement

Maintenance is aim to keep network system. The process covers upgrade bandwidth in order to make system stable while using in heavy traffic. The system after going maintenance process should be consistent in layout.

\subsection{Design Phase}

The prototype design phase is started from determining the right interface element, a suitable function for the user to complete the task and make the user understand and use the system easily [7]. The design is developed based on user recommendation in previous phase.

\subsection{Validation / Evaluation Phase}

The results of the prototype design of the interactive version of the student information system are evaluated by real user i.e students. The user testing method is fully utilized during the system testing process. The selected method of assessment is questionnaire.

\subsection{Delivery Phase}

After the prototype is developed and evaluated, the prototype is ready for use by the user. Five activities on this UCD are iterative to obtain a prototype that meets the needs of users based on test results.

\subsection{Sample of Research}

The sample research refers to the small part representing an appropriate population as an example for the study [9]. The sample for this study was graduate students at the Faculty of Science and Information Technology, Universiti Kebangsaan Malaysia.

\subsection{Research Instrument}

For the purpose of this study, the researcher provided a set of questionnaire forms to be distributed to identify research samples. Question form is closed by using Likert scale type. The Likert scale is commonly used in a format that makes it easier for researchers to analyze the data obtained [9]. 


\subsection{Data analysis}

Data interviews were analyzed using content analysis methods as this method was suitable for textual data. The researchers used the Alpha Cronbach $(\alpha)$ method which was conducted on the respondents' feedback by 30 respondents. Alpha Cronbach points out that research items are interconnected with each other. Sekaran (2003) [9] proposes only $\alpha>0.6$ values that can be used in the questionnaire. The value of $\alpha=0.8$ is considered good and accepted in the questionnaire, while the values of $\alpha=0.6$ and $\alpha=0.70$ are acceptable.

\section{Result and Discussion}

There are various methods that can be used to run system testing. The main thing to be identified in user testing is the reliability test to see the consistency of questionnaire items with expected test results.This study using Alpha Cronbach $(\alpha)$ method to respond to questionnaire by 30 respondents. A detailed test has been done on the criteria of usefulness according to the items provided and the results obtained are as shown in Table 1.

Table 1. Reliability Test Score Usability Criteria

\begin{tabular}{|c|c|c|}
\hline Criteria & Number of Problem & 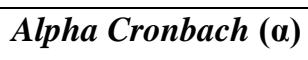 \\
\hline Understandability and Learnability & 6 problems & 0.90 \\
\hline Functionality & 7 problems & 0.79 \\
\hline Interactivity & 3 problems & 0.74 \\
\hline Error and Recovery & 6 problems & 0.86 \\
\hline Interface standards & 10 problems & 0.87 \\
\hline
\end{tabular}

Based on Table 1, the result of the test was found that the criterion of understanding and the learner obtained the highest $\alpha$ score of 0.90 , followed by the criteria of interface standard 0.87 , error and recovery criteria 0.859 , functionality criterion 0.79 and interactivity criterion 0.74 . Based on the results of the questionnaire reliability test question using internal consistency method with Alpha Cronbach value more than 0.70 indicates good and acceptable questionnaire items. Therefore, studies have determined that to retain and use all the five usefulness criteria proposed in the questionnaire instrument for the evaluation of the system version 2.0 system is usable.

\section{Conclusion}

Based on the results of the data analysis, it shows that the usability and functionality impact to system usage. Both of these factors are needed to ensure the usefulness of the proposed system is achieved. This technique was developed based on literary highlights, requirement analysis studies and prototype evaluation by actual users through questionnaire. This study describes the necessary criteria in usability factor of the graduate student information system. Overall, the graduate student information system version 2.0 has been developed according to usability models. 


\section{REFERENCES}

[1] A. Jin, "On the Development of College Student Information Management System”,SHS Web of Conferences. 2015.

[2] N. Obasi, O. Nwakchukwa, and C. Ugwa, "A Novel Web-Based Student Academic Records Information System", West African Journal of Industrial and Academic Research, vol. 7, no.1, pp :31-47. 2013.

[3] C.A. Reyes, "Students' Information System and Services", Int'l Conference Image Processing, Computers and Industrial Engineering (ICICIE), 2014

[4] D. Wallach and S. C. Scholz, "User-Centered Design: Why and How to Put Users First in Software Development", in Maedche, A, Botzenhardt, A, \& Neer, L (eds), Software for People, Springer, Germany, pp. 11-38. 2012

[5] S. Roy, P.K. Pattnaik, and R. Mall, "A quantitative approach to evaluate usability of academic websites based on human perception", Egyptian Informatics Journal. vol. 15, no.1, pp: 159167. 2014.

[6] L. Hasan, "The usefulness of User Testing Methods in Identifying Problems on University Websites", Journal of Information System and Technology Management, vol. 11, no.2, pp: 229-256. 2014.

[7] P. Weichbroth and M. Sikorski, "User Interface Prototyping, Techniques, Methods and Tools. Gdansk University of Technology, Gdansk", 2015.

[8] O. Talib, "Asas Penulisan Tesis Penyelidikan \& Statistik", Penerbit. Universiti Putra Malaysia. 2013

[9] G.B. Shelly and H.J. Rosenblatt, “Analysis and Design for System" 9th Edition. Shelly Cashman Series. 2012. 